\title{
Social Customer Relationship Management: A Process Model Approach to Develop a Closer Relationship Between Customer and Company
}

\author{
Gamal Kassem ${ }^{1}$, Evan asfoura ${ }^{2}$, Stefan Willi Hart ${ }^{3}$, Sulaiman Althuwaini ${ }^{4}$ \\ ${ }^{1}$ Dept of BIS, German University in Cairo, Cairo, Egypt \\ ${ }^{2}$ Dept of Accounting, Arab open University, Riyadh, Saudi Arabia \\ ${ }^{3}$ Dept of BIS, Otto Von Cuierike University, Magdeburg, Germany \\ ${ }^{4}$ College of business studies, Arab Open university, Riyadh, Saudi Araba
}

\begin{abstract}
With the rise of social networks, blogs and other platforms, where people meet and exchange ideas, the opportunity arises not only to address a group of customers but also to address potential customers individually and directly. Social CRM plays here an important role. Social Customer Relationship Management is using social and media services, techniques, and technology that enable an organization to engage with their customers. Thus, Social CRMs offer companies the chance not only to establish a direct contact with the customer to get a close relationship, but also to collect important information about the customer. This paper analyzes the classical model of social CRM process and presents a new process model idea. The model will provide processes to develop close and intense relationship between customers and companies.
\end{abstract}

Keyword - Customer relationship management, social costumer relationship management, social network, social media.

DOI: $10.18421 /$ TEM111-25

https://doi.org/10.18421/TEM111-25

Corresponding author: Evan Asfoura,

Dept of Accounting Arab open University Riyadh,

Saudi Arabia.

Email: e.asfoura@arabou.edu.sa

Received: 16 June 2021.

Revised: 13 January 2022.

Accepted: 20 January 2022.

Published: 28 February 2022.

(cc) BY-NC-ND (C) 2022 Gamal Kassem et al; published by UIKTEN. This work is licensed under the Creative Commons Attribution-NonCommercial-NoDerivs 4.0 License.

The article is published with Open Access at https://www.temjournal.com/

\section{Introduction}

This research is designed to develop conceptual model which will manage and operate closer relationship between customer and company using social media. Therefore, conceptual SCRM based process model for closer relationship between customer and company is proposed as a result of this paper. The research is designed in three stages.

First, a comprehensive literature research is performed to gather the main requirements needed to construct the proposed conceptual framework. From one side, related works from technical and social perspectives were analyzed. From the other side, existing practiced methods dealing with customers using social media were investigated in literature and via interviews with companies' representatives and social media user during CEBIT-2018 Germany as well.

Second, based on requirements and Is-As methods and models as results from the first step a detailed conceptual framework is developed. We conducted semi structured interviews with academic and industry experts in the area of management, information systems, and computer science to involve them during the development stage. Thereby, DELPHI method is used [20], so that the iterative development process insure high grade of correctness and completeness.

In the third stage we planned to implement the framework in real business in near future in order to evaluate it in real business life.

\section{Related Works and Background}

During an interview with a representative of a company, he said in a survey at the -2018 an ITtrade show in Germany: "I've noticed this week that we need to boost our position in social media. Our business partners find it easier to get into 
conversation by social media because they have a personal area by their social network". This was the conclusion of the company's representative at CEBIT after he has seen one of his business partners, as he has uploaded a video on using social media the week before. Studies show that already $71 \%$ of the companies surveyed use social media [5]. Social media are platforms that support the user via digital channels in mutual communication and support interactive information. Thus, many companies have responded to this trend and are using now the new communication channels in order to present themselves. The next central question for the company now is: How could we use these new channels to achieve more business goals?

Through communication over social media, company can improve the customer relations and evaluate their behavior. Since Apple's success regarding tie-up a huge loyal customer community, companies are looking more and more for a way to build a corporate culture with a customer. Social media can tackle such a possibility. It offers companies the chance to open up to customers.

A traditional Customer Relationship Management (CRM) is defined by Paul Greenberg, as a business philosophy and strategy to see which is supported by a technology or system to improve human interaction in an enterprise [1], [2]. According to Greenberg, a Social CRM (SCRM) is an extension of this philosophy and strategy supported by information technology, and customized by business rules, business processes and social characteristics. By using it, customer and company are involved in discussions to offer attractive benefits for both sides. This communication should be done in a transparent and trustworthy context. There are also some researches focused on the role of social media in enhancing costumer involvement and improving the customer relationship management efficiencies and effectiveness especially by the small and medium sized enterprises (SMEs) [16] because of the attractiveness of social media as communication channel for costumers [17], [18], [19]. That supports the importance of SCRM against the traditional CR.

A traditional CRM is based on an internal operational process in order to manage the customer relationship effectively. While a SCRM is the combination of social media and CRM, and therefore it is considered as more than an extension of traditional CRM. The goal of a SCRM is to use new social and collaborative technologies by customer contact. SCRM uses the benefit of social media to manage collaborative processes for creation, distribution, modification and processing of information of the customer relationship with the company.

A simple CRM system typically consists of the following three components: Analytical, Operational and Collaborative CRM [6], [20]. While in a SCRM system, seven components can be identified [7]. Each SCRM system has a search engine; the search engine is used in real time to find out new content or source. The found content are then intercepted and analyzed by the social media monitoring-component of the SCRM. The business intelligence tool takes the intercepted data and consolidates it into CRM component of SCRM as structured data and unstructured social web data. There are five different data sources, which the business intelligence tool analyzes and sorts as structured or unstructured data. The social web data includes the contents of posts; the so-called posting body, which is filtered for example by opinions, keywords, topics/titles, and links, so that they can present the dependencies between posts and profiles. Unstructured data can be collected only by using text-mining tools and then it has to be updated and structured to take advantage of them. Structured data is, however, easier to collect as they are collected from Extract, Transform, Load tools (ETL-tools) and do not need to be updated afterwards. This category of data sources includes the posting envelope, the profile bodies and the profile envelope. The profile envelopes are the metadata of the user profiles stored as information about friends and activities. The body of each profile consists of profile data including for instance name, age and hobbies. Posting envelopes are metadata of mail and it includes the author and subject or source. This data can be used by the CRM component. The CRM component manages and organizes all SCRM activities in combination with other CRM processes. The Social Media Management supports and coordinates the use of communication via social media. The sixth component is social network analysis. This component identifies communication flows and dependencies between social media users. The last component is the community component that helps to establish social interactions between community users.

Finally, there are four functional elements provided: Monitoring, Management, Interaction and Analysis functions.

The traditional CRM has evolved through the rise of social media, not only in design, but also in its objectives to address customers directly and personally to bind the customer to the company. Personal and direct response to the customers should be encouraged with the proposed process model. 


\section{Research Methodology}

This work aims to develop a model based on two different perspectives, one from process technical perspective and the other one from customer sociological perspective. The process view explains "what and how". This means, how the process runs and what elements are involved in the process - and the sociological view that explains about "why" why the process behaves.

The procedural basis of the proposed SCRM lifecycle is based on four main process phases: Listening, Preparation, Act, and Measurement, which are abstracted and deduced from media literature and technical reports dealing with interaction with customers spicially the social media, for example in [3], [21], [22]. In the first phase of the process, the monitoring tools intercept activities of social media communities and gather selected monitoring data. Afterwards, the data is collected as information into different formates. There are structured and unstructured information data. In the preperation process phase, the collected information will be processed, analyzed to be used in the subsequent act phase. The result of the analysis is used to facilitate the contact with the customer. The Act phase is the phase in which an employee will contact actively by a contact request in order to come into dialog with the customer. The last phase of the process deals with the measurement of the dialog. In this phase, it will measure the success of the conversation and measure the success of business activities and to assess the customer opinion about products or services.

The sociological basics of the process modeling approach is based on the friendship model by Herb Goldberg on one hand [15], on the other hand it considers the basic needs of humans in society. Humans are social beings, so-called "homo sociologicus". The contact and interaction with other people plays an important role in human life. According to Kneidinge there are two basic approaches to investigate in building a friendship [12]. Firstly, it is the social needs and secondly, the social balance. The approach of social needs expects that a human forms relationships to satisfy his needs for intimacy, self-esteem and society. The other approach is based on the friendship that forms out of a conflict. On the basis of this approach people have social needs that will be analyzed in this work. One would like to go from so-called "significant ties" to "core ties". "Significant ties" are relationships where there is no regular contact and little support is expected from other. In contrast, a "core ties" is the connection in which the regular contact is present. The people in this connection have further help and support for each other. Thus, the "significant ties" are similar to acquaintances and are weaker than the "core ties", but in certain situations where information or assistance is needed, they could be important partners in the network. The goal of a company should be to build up a close social relationship to the customer. According to Max Weber, "A Social relationship of humans is a sense common content and it mutually adjusted for each as a behavior of multiple oriented perspectives. The chance that we act in a meaningful (sensuously) manner based on the benifit of the opportunity" [13]. The friendship is the most important form of social relationship. Friendship is defined as "a social relationship based on affection and specific purposes (companionship, help and mutual support)" [14].

Companies now want to build a close social relationship with customers, where the goal is to attract them as friends and that has to be on the basis of mutual support. Another important aspect is that the employees have to be well trained in dealing with customers, especially in the area of social media.

The so-called "active listening" is an important tool. Steil provide a four-stage model. The first stage is the perception (listening), for example, body language, followed by the interpretation of the perception. Then the conversation will be assessed and an appropriate response is initiated. The reaction can take place verbally and nonverbally according to the model [8]. In our case, we analyze the activities of the user and interpret, evaluate, and respond it. Goldberg describes the various stages of friendship in a four-stage model. The first stage is the manipulative stage and it is closed only, as long as both parties benefit from each other. Then companionship phase follows. This phase of friendship supposed that all parties joined voluntarily to each other in order to achieve a particular goal. After the companionship phase comes the friendship that characterizes the people meetings without specific goals or motivation, and spending time together. The final stage is the socalled buddyship. This sociological model is applied in the act process of our model.

The act process is divided into two levels and each level forms a phase of the friendship model by Goldberg. It will be shown only the first be mapped in the two stages of the friendship model, because friendship in the strict sense cannot arise between employee and customer The first sub level of the active process is similar to the manipulative stage. A customer has a problem and the employee wants information. Both have different objectives and they can create personal added value only when they work together. The purpose of friendship is 
displayed in the second level and is reached when the customer accepts the friend request of the employee. While both still have personal goals, the main target of the company to improve the products is also considered.

It is difficult to define the concept of friendship in this environment. Therefore the concept of friendship needs to be clearly defined. The friendship between employees and customers undergoes the win-win concept and both sides want to reach certain goals or benefits from these social relations. For such cases, friends in such a relationship cannot be built by traditional strategic approach of CRM systems. The goal is to expand the traditional CRM system to integrate with the functionalities of Social CRM.

\section{Social Customer Relationship Management Process Model}

This section describes the individual, main and secondary processes of social customer relationship process model. It addresses the four main processes: Listening, Analyze and Prepare, Act, and Measurement. All four phases will be described and detailed in sequence with their inputs and outputs. The process model is a closed loop as a life cycle process (see Figure 1).

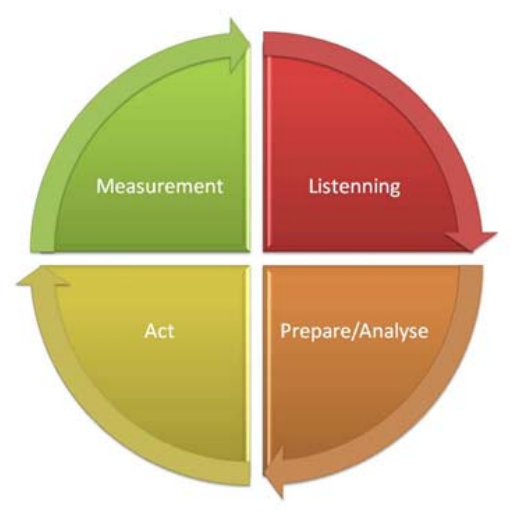

Figure 1. SCRM Lifecycle

\subsection{Listening Phase}

The process model always starts with the listening phase. In this phase, all activities of the community that are taking place within social media were added. Therefore, the start point of the process is the community. A community consists of members and many of them are active in social media.

The initial point of the model suggested that customers are subset of a social media community. This group posts, comments or likes comments. Recommendations, ratings, or reviews can be published in this group. Such activities are observed by so-called monitoring tools. As already described in the previous section, different type of data can be intercepted and filtered. The following example will illustrate the process steps. A customer of a community is logged in one social network and has a technical problem with a specific product or service. She or he is very much angry about this problem and posts his problem on the fan page of the related company. This post is registered and then the monitoring tool is used to learn more about the disgruntled customer. The collected data is then passed to the CMS system. Thus, it goes to the next prepare/analysis process.

\subsection{Analyze and Prepare Phase}

In this phase of the process model, the information collected from the customers will be analyzed and used for prepare interact with him. In the CRM system, the intercepted data are categorized and structured. The information are filtered then passed to the Social CRM team. This team consists of employees of the company who have been trained specifically for the new communication channels.

A team member will now receive the information from the CRM system, that a customer has a problem or the criticism remarked in a monitor channel. The system sends the information to the employee with following data:

- Used channel

- Customer profile information

- Previous customer activities (in general)

- The following customer activities (in general)

- Previous customer activities associated with the company

- Contents of the problem or criticism

- Mood trends of the customer

Before the employee is informed, the CRM system analyzes the customers on value. Is the value of customer greater than the service costs which can arise during the course of the process, the customer is valuable and will be contacted. If the results of a cost-benefit analysis are showing negative values, the contact is not very economic, as the costs of the contact are higher than the benefit. Thereby, the historical collected data of the customer and experience from conversations with similar types of customers are considered by customer contact decision making. If the employee is informed by the system, then the relationship status between the customer and the company plays here crucial role. If the customer is already known to the company and referred to the second stage "relationship", then the employee addresses the customers directly. Based on preliminary information, the employee can create a user contact and conversation strategy that meets company strategy. After the employee has prepared on conversation, it goes to the next process phase, "Act". 


\subsection{Act Phase}

After the analysis and preparation, the act phase begins with a process step "decision". The staff of the Social CRM team should decide on the basis of the data whether a universal answer or a personal response should be given to the customer's comment. With the universal or standard response, the employees have the ability to give indirect assistance to the customer.

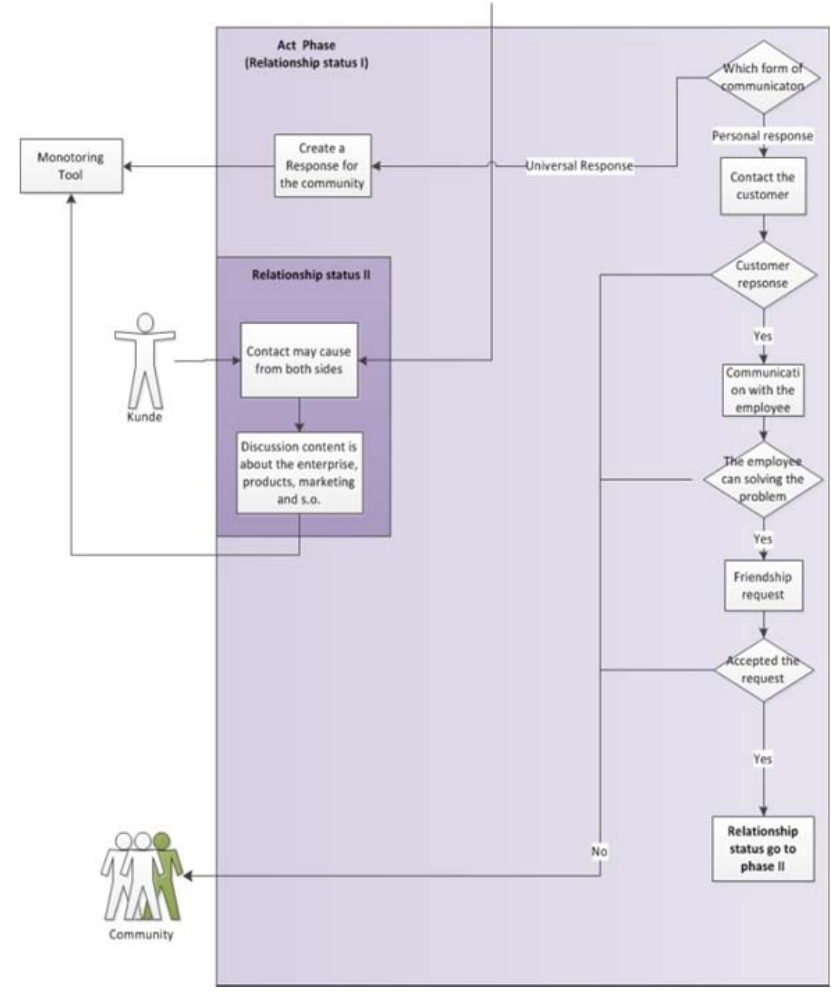

Figure 2. Act Phase

The employee who operates direct contact with the customer watches only the status of the customer monitored by the system. In case that the customer and the staff have already achieved the level of "friendship", the sequence of the process takes now different flow. Both parties already know each other, so that less inhibiting barriers exist and it makes more open communication possible. It may be the case that the employee is contacted by the customer, since the employee already gained his confidence by previous contacts. If this is not the case, the employee tries to come into contact with the user either by a personal message or a post on the profile page. If customer responds were positive, exchange of information is performed. Aim of this information exchange is to keep the contact at the first sub-stage of the act phase and to solving customer problem. In the case that the customer rejects or ignored the contact request, the employee archives the collected information in the CRM system (see Figure 2). This information will be used for future contact to increase the success rate of a user contact.
Furthermore, the information will be used for the evaluation the process itself.

If the customer responds, then the employee tries to solve the customer problem. A complete conversation history is recorded and stored in the CRM system. This will be used later to solve similar customer problems. The system provides a longer time period of the Problem-Solution-Wiki where employees look for customer problems and can read all related possible solutions. At the end of the consulting the customer, the employee of social CRM team offers the customer his readiness for further future supports by sending a friend request to the customer.

Table 1. Stages of the first step of process Act

\begin{tabular}{|c|c|}
\hline 1.Stage & 2.Stage \\
\hline $\begin{array}{l}\text { One-way communication } \\
\text { The employee starts the } \\
\text { dialog. }\end{array}$ & $\begin{array}{l}\text { Two-way communication } \\
\text { The customer may select } \\
\text { specific employee } \\
\text { personally and directly. }\end{array}$ \\
\hline $\begin{array}{l}\text { Only one talking point: } \\
\text { The main talking point is } \\
\text { customer problem and its } \\
\text { solution. Other issues } \\
\text { play a minor or no role. }\end{array}$ & $\begin{array}{l}\text { Expansion of the talking } \\
\text { points: } \\
\text { Solving customer problems } \\
\text { still has the priority. } \\
\text { Topics such as product } \\
\text { development, product } \\
\text { marketing and enterprise } \\
\text { strategies are also } \\
\text { considered. }\end{array}$ \\
\hline $\begin{array}{l}\text { Conservative } \\
\text { communication }\end{array}$ & $\begin{array}{l}\text { Complementary } \\
\text { transaction: } \\
\text { Customer and employee } \\
\text { perform a communication } \\
\text { on the same personal level. } \\
\text { The dialogue can be open, } \\
\text { transparent and objective, } \\
\text { since both communicate to } \\
\text { the adult-ego level } \\
\text { together. }\end{array}$ \\
\hline
\end{tabular}

The customer can either accept or reject the request. If the customer accepts so-called "friendship request", the customer's status is changed. The customer is now in the friendship circle of the company. Accepting the friendship request causes a modification of the relationship between the parties. Before accepting the friendship request, the relationship was just a commercial relationship and the next stage of the relationship is now is so-called "purpose of friendship", which is resulting the change of the customer status from normal customer to friend. There are the following differences between the first stage and the second stage of the first step of the Process Act (see Table 1).

Now, the contact and the communication strategy are different between stages 1 and stage 2, because of change of the communications types from a very cautious and reserved communication by mostly active listening towards an open communication. 
If the customer declines the friend request, then all customer conversation information collected and stored in the CRM system are re-used for future contact recordings. The most important point in this process phase is that the collected information is stored at any time in the CRM system. It is all about creating add value for the company at this stage. Even rejected friend requests or ignored friend requests achieve an add value for information. This information can be used in the next phase of the process, the measurement phase to improve different various internal or external enterprise business processes and also to improve enterprise strategies.

\subsection{Measurement Phase}

In the measurement phase, the employee uses the collected information during the customer dialogue in Act phase and/or uses the data that recorded by monitoring tools. This data is all stored in the CRM system.

From this information, Key Performance Indicators (KPIs) are created to have an enhanced measurement of the success of social CRM. According to a study of Peppers \& Rogers Group, 38 percent of companies do not consider the effectiveness of the measurements [4].

In order to guarantee long-term success for social CRM systems and the process of this model is a measurement of success is required. Such process measurement has to be continually evaluated to be used as a basis for the preparation of social media activities itself.

After analyzing the indicators new business rules or the updated business rules can be implemented. Business rules are needed to simplify the process flow and to ensure the quality of service and primarily to increase the chance of accepting a friend request in a Social CRM system. Furthermore, the results are used to improve the decision making in other enterprise strategically areas like marketing and business process improvement, as well as to improve the product quality and product development. Table 2 shows examples for KPIs for measuring and evaluation of social CRM success.
Table 2. KPIs Examples

\begin{tabular}{|c|c|c|}
\hline $\begin{array}{c}\text { Key Perfomance } \\
\text { Indicator }\end{array}$ & Description & $\begin{array}{c}\text { Software } \\
\text { vendors }\end{array}$ \\
\hline $\begin{array}{l}\text { Participant } \\
\text { Influence }\end{array}$ & $\begin{array}{l}\text { All posts of a } \\
\text { participant that } \\
\text { influences } \\
\text { directly or } \\
\text { indirectly in } \\
\text { social media } \\
\text { conversations. }\end{array}$ & $\begin{array}{l}\text { Cymfony, Jive, } \\
\text { Lithium, } \\
\text { Radian6, } \\
\text { Razorfish (SIM } \\
\text { Score), SAS, } \\
\text { Telligent, } \\
\text { Twitalyzer }\end{array}$ \\
\hline $\begin{array}{l}\text { Problem } \\
\text { Solving Rate }\end{array}$ & $\begin{array}{l}\text { The share of } \\
\text { solved problems } \\
\text { in relation to the } \\
\text { sum of service } \\
\text { requests via } \\
\text { social media } \\
\text { channels. }\end{array}$ & $\begin{array}{l}\text { Jive, RightNow } \\
\text { Technologies } \\
\text { Salesforce.com, } \\
\text { Telligent }\end{array}$ \\
\hline $\begin{array}{l}\text { Problem } \\
\text { Solving Time }\end{array}$ & $\begin{array}{l}\text { The time units } \\
\text { that required in } \\
\text { average to } \\
\text { respond a service } \\
\text { request via social } \\
\text { media channels. }\end{array}$ & $\begin{array}{l}\text { Jive, RightNow } \\
\text { Technologies } \\
\text { Salesforce.com, } \\
\text { Telligent }\end{array}$ \\
\hline Trend Rate & $\begin{array}{l}\text { The share of the } \\
\text { specific topics } \\
\text { mentioned } \\
\text { related to all of } \\
\text { the topics within } \\
\text { the social media } \\
\text { channels. }\end{array}$ & $\begin{array}{l}\text { Alterian SM2, } \\
\text { Cymfony, Jive, } \\
\text { Radian6, SAS, } \\
\text { Scout Labs }\end{array}$ \\
\hline $\begin{array}{l}\text { Innovative } \\
\text { Power }\end{array}$ & $\begin{array}{l}\text { Innovation } \\
\text { Power is the } \\
\text { share of positive } \\
\text { commitment of a } \\
\text { product related } \\
\text { to all comments } \\
\text { of best products. }\end{array}$ & $\begin{array}{l}\text { Biz360, } \\
\text { Cymfony, Jive, } \\
\text { Lugiron, } \\
\text { Radian6, Scout } \\
\text { Labs, Visible } \\
\text { Technologies }\end{array}$ \\
\hline
\end{tabular}

\section{Result \& Discussion}

The model has its strengths and weaknesses. Primarily, there are four major weaknesses. Firstly, the system integration is the main problem especially the integration of social CRM software into the existing system integration. Furthermore, the existing customer data integration has to be considered as an automated forwarding of important conversations with employees. Another weak point is the implementation, it is very resource consuming. There will be a lot of employees needed who are trained to deal with social media, and need to have skills in customer communication. 
The most critical point is the data protection for privacy. There are two types of data - personal data and anonymous data. Personal data is data which provides details about personal or material information of an identified or identifiable natural person [9].

Only personal data are critical for the proposed process model. This data is protected in Germany by the Federal Data Protection Act (BDSG) and the Telemedia Act (TMG). An open and transparent strategy for all users would be particularly useful, because of the active participation of users in today's generation.

A self-survey carried out at CeBIT 2014 showed that while $93 \%$ of respondents are registered in a social network, but only $35 \%$ are regularly look at company profiles. But the next generation is growing up with these new media. This means that the next generation probably pushes their skepticism and is more open to such offers.

The survey at CeBIT already showed a tendency that especially the age group of $16-25$ is willing to use such a service. The strengths of such a model is the clearly approach to get a strong insight into the customer's perspective. This means, the company could offer a service channel and get better understanding of the customer. It has a huge amount of potential sources of information. As mentioned above, such information may be useful in various departments of a company and bring a new dimension in the areas of marketing, product development and process efficiency. The question is of course is how much the returns on investment value will be at the end? The implementation effort is enormous, and the resource requirements of the resulting success can still be daunting. One should always keep in mind that there are currently about 964292680 active users using Facebook [10].

An overview of all the continents shows that a high percentage of the population is active on Facebook (see Table 3). Exceptions are the continents of Asia, because China has its own social networks (Qzone, RenRen), and Africa (Internet connection) [11].

Table 3. Active populations on Facebook

\begin{tabular}{|c|c|c|}
\hline Continent & $\begin{array}{c}\text { Users } \\
\text { (in million) }\end{array}$ & Penetration \\
\hline Asia & 768 & $6,63 \%$ \\
\hline Europe & 131 & $30,18 \%$ \\
\hline North America & 283 & $43,81 \%$ \\
\hline South America & 197 & $36,41 \%$ \\
\hline Africa & 74 & $4,96 \%$ \\
\hline
\end{tabular}

A platform on which so many potential customers are active should have to use. Especially, these channels are using not only in the $\mathrm{B} 2 \mathrm{C}$ sector, but also in the B2B sector. Companies could use social media to get information about suppliers, share information or to maintain business contacts.

Companies should recognize the opportunities arising. A successful implementation of this process model can not only increase the customer loyalty, but can also ensure the product quality. One would not miss trends, such as Nokia by missing the Smartphone trend.

The next step is the technical process and implementation of the model in an organization to take the experience and to evaluate the model.

\section{Conclusion}

This paper proposed a systematic process model related to operating SCRM which consists of four main phases: Listening, Analyze and Prepare, Act, and Measurement. Each phase has input and provides output used as input for the following phase. These phases have been derived based on two different perspectives, one from process technical perspective and the other one from customer sociological perspective. The process view explains "what and how"; how the process runs and what elements are involved in the process - and the sociological view that explains about "why" - why the process behaves. The strengths and weakness of the proposed model has been discussed deeply in the result section.

\section{Acknowledgment}

The researchers extend their thanks and gratitude to the Arab Open University for the support and funding of the , "Social Customer Relationship Management" as one year research project which this paper belongs to.

\section{References}

[1]. Greenberg, P. (2010). CRM at the speed of light: Social CRM strategies, tools, and techniques. New York: McGraw-Hill.

[2]. Kneidinger, B. (2010). Facebook und Co.: Eine soziologische Analyse von Interaktionsformen in Online Social Networks. Springer Science \& Business Media.

[3]. Porr, S. (2011). Das Versprechen Kundendialog kann endlich eingelöst werden-Social Media in der B2C-Kommunikation. In IT-Berater und soziale Medien (pp. 183-189). Springer, Berlin, Heidelberg.

[4]. Greve, G. (2011). Social CRMZielgruppenorientiertes Kundenmanagement mit Social Media. In Online Targeting und Controlling (pp. 261-285). Gabler. 
[5]. Ahlden, A. (2012). Braucht jede Marke eine Facebook-Fanpage?. In Social Branding (pp. 43-63). Gabler Verlag, Wiesbaden.

[6]. Helmke, S., Uebel, M. F., \& Dangelmaier, W. (2008). Grundsätze des CRM-Ansatzes. In Effektives Customer Relationship Management (pp. 3-24). Gabler.

[7]. Reinhold, O., \& Alt, R. (2012). Social Customer Relationship Management: State of the Art and Learnings from Current Projects. Bled eConference, 26.

[8]. Steil, L. K., Summerfield, J., \& DeMare, G. (1986). Aktives Zuhören: eine Anleitung zur erfolgreichen Kommunikation. Sauer.

[9]. Eickmeier, F., \& Hansmersmann, P. (2011). Datenschutzkonforme Nutzerprofile im Internet. In Online Targeting und Controlling (pp. 95-121). Gabler.

[10]. Unified Social Media Marketing Platform. (2021). Facebook statistics by continent. Retrieved from: www.socialbakers.com, [accessed: 10 May 2021].

[11]. SproutSocial.(2021). 20 Facebook stats to guide your 2021 Facebook strategy. Retrieved from: https://sproutsocial.com/insights/facebook-stats-formarketers/ , [accessed: 15 May 2021].

[12]. Kneidinger, B. (2010). Facebook und Co.: Eine soziologische Analyse von Interaktionsformen in Online Social Networks. Springer Science \& Business Media.

[13]. Weber, M. (2002). Wirtschaft und gesellschaft: Grundriss der verstehenden Soziologie. Mohr Siebeck.

[14]. Biedermann, H. (2006). „Entwicklung der sozialen Kognition: Perspektivenübernahme und Freundschaftsentwicklung “. Freiburg: Departement Erziehungswissenschaften der Universität Freiburg.
[15]. Goldberg, H. (2000). The hazards of being male: Surviving the myth of masculine privilege. Wellness Institute, Inc..

[16]. Cheng, C. C., \& Shiu, E. C. (2019). How to enhance SMEs customer involvement using social media: The role of Social CRM. International Small Business Journal, 37(1), 22-42.

[17]. Guha, S., Harrigan, P., \& Soutar, G. (2018). Linking social media to customer relationship management (CRM): A qualitative study on SMEs. Journal of Small Business \& Entrepreneurship, 30(3), 193-214.

[18]. Marolt, M., Zimmermann, H. D., \& Pucihar, A. (2018). Exploratory study of social CRM use in SMEs. Engineering Economics, 29(4), 468-477.

[19]. Aldaihani, F. M. F., \& Ali, N. A. B. (2018). Impact of social customer relationship management on customer satisfaction through customer empowerment: A study of Islamic Banks in Kuwait. International Research Journal of Finance and Economics, 170(170), 41-53.

[20]. Seeger, T. (1979). Die Delphi-Methode: Expertenbefragungen zwischen Prognose und Gruppenmeinungsbildungsprozessen; überprüft am Beispiel von Delphi-Befragungen im Gegenstandsbereich Information und Dokumentation. Hochschul-Verlag.

[21]. Mertens, P. (2013). Integrierte Informationsverarbeitung 1-Operative Systeme in der Industrie (18. Aufl.). Wiesbaden: Gabler.

[22]. Hart, S. W., \& Kassem, G. (2012, June). Social customer relationship management-From customer to friend. In European, Mediterranean and Middle Eastern Conference on Information Systems (pp. 78). 